\title{
Effects of salubrinal on development of osteoclasts and osteoblasts from bone marrow-derived cells
}

\author{
Hiroki Yokota ${ }^{1,2^{*}}$, Kazunori Hamamura ${ }^{1}$, Andy Chen ${ }^{1}$, Todd R Dodge ${ }^{1}$, Nancy Tanjung ${ }^{1}$, Aysan Abedinpoor ${ }^{1}$ \\ and Ping Zhang ${ }^{1,2,3^{*}}$
}

\begin{abstract}
Background: Osteoporosis is a skeletal disease leading to an increased risk of bone fracture. Using a mouse osteoporosis model induced by administration of a receptor activator of nuclear factor kappa-B ligand (RANKL), salubrinal was recently reported as a potential therapeutic agent. To evaluate the role of salubrinal in cellular fates as well as migratory and adhesive functions of osteoclast/osteoblast precursors, we examined the development of primary bone marrow-derived cells in the presence and absence of salubrinal. We addressed a question: are salubrinal's actions more potent to the cells isolated from the osteoporotic mice than those isolated from the control mice?
\end{abstract}

Methods: Using the RANKL-injected and control mice, bone marrow-derived cells were harvested. Osteoclastogenesis was induced by macrophage-colony stimulating factor and RANKL, while osteoblastogenesis was driven by dexamethasone, ascorbic acid, and $\beta$-glycerophosphate.

Results: The results revealed that salubrinal suppressed the numbers of colony forming-unit (CFU)-granulocyte/ macrophages and CFU-macrophages, as well as formation of mature osteoclasts in a dosage-dependent manner. Salubrinal also suppressed migration and adhesion of pre-osteoclasts and increased the number of CFU-osteoblasts. Salubrinal was more effective in exerting its effects in the cells isolated from the RANKL-injected mice than the control. Consistent with cellular fates and functions, salubrinal reduced the expression of nuclear factor of activated T cells c1 (NFATc1) as well as tartrate-resistant acid phosphatase.

Conclusions: The results support the notion that salubrinal exhibits significant inhibition of osteoclastogenesis as well as stimulation of osteoblastogenesis in bone marrow-derived cells, and its efficacy is enhanced in the cells harvested from the osteoporotic bone samples.

Keywords: Osteoporosis, RANKL, Salubrinal, Osteoclasts, Osteoblasts

\section{Background}

Osteoporosis is a common skeletal disease of bone loss, which leads to an increased risk of bone fractures, morbidity, mortality, and an economic burden to society [1-3]. In many cases it is a physiological consequence of the aging process $[3,4]$, and in postmenopausal women it is induced by a decrease in the production of estrogen, a hormone known to maintain the appropriate ratio of bone-forming osteoblasts to bone-resorbing osteoclasts

\footnotetext{
*Correspondence: hyokota@iupui.edu; pizhang@iupui.edu

'Department of Biomedical Engineering, Indiana University-Purdue University Indianapolis, 723 West Michigan Street, SL220, Indianapolis, IN 46202, USA

${ }^{3}$ School of Basic Medical Sciences, Tianjin Medical University, Tanjin 300070,

People's Republic of China

Full list of author information is available at the end of the article
}

[5]. During the past 20 years, many therapeutic drugs have been developed to prevent osteoporotic bone loss. Bisphosphonates are the most widely prescribed medications to treat postmenopausal osteoporosis, but they may be associated with an increased risk of osteonecrosis of the jawbone and atypical femur fracture [6]. Other treatments include administration of estrogen and estrogen analogs, as well as parathyroid hormone. However, increased risks of breast cancers and blood clots have been reported as side effects of these treatments [7-9]. The aim of this study is to evaluate a therapeutic role of a chemical agent, salubrinal, in potential treatment of osteoporosis.

Salubrinal is a small chemical agent $(480 \mathrm{Da}$, $\mathrm{C}_{21} \mathrm{H}_{17} \mathrm{Cl}_{3} \mathrm{~N}_{4} \mathrm{OS}$ ) known to block de-phosphorylation of

\section{Biomed Central}


eukaryotic translation initiation factor 2 alpha (eIF2 $\alpha)$ [10]. Salubrinal is also reported to attenuate molecular signaling mediated by nuclear factor kappa B (NFkB) [11]. The elevated phosphorylation level of eIF2 $\alpha$ upregulates activating transcription factor 4 (ATF4), one of the key transcription factors in bone formation [12]. Salubrinal is shown to enhance healing of bone wounds and promotes differentiation of osteoblasts [13]. Little is known, however, about its effects on bone resorption, in particular developmental regulation of bone marrow-derived cells. Bone marrow-derived cells contain mesenchymal stem cells (MSCs) and hematopoietic stem cells that give rise to osteoblasts and osteoclasts, respectively [14]. The primary focus of this study is the potential role of salubrinal in the development of bone marrow-derived cells towards mature osteoclasts, as well as its role in development of mesenchymal stem cells and osteoblasts.

Experimental animal models are useful to evaluate therapeutic efficacy of chemical agents. Available osteoporosis models include ovariectomy (OVX) [15,16], tail suspension $[17,18]$, denervation $[19,20]$, a low-calcium diet [21,22], and administration of receptor activator of nuclear factor kappa-B ligand (RANKL) [23-25]. Any animal model may have its advantage and disadvantage. For instance, OVXinduced osteoporosis, which is currently considered as the gold standard for the evaluation of pharmaceuticals for postmenopausal osteoporosis, not only reduces the level of estrogen but also generates surgery-induced injury together with an increase in osteoblast activity. Furthermore, surgical induction of OVX requires consistency in the surgical procedure as well as a minimum of 4 weeks. The tail suspension model not only increases bone resorption but also reduces osteoblast differentiation. In the denervation model, surgery-induced injury is involved. In this study, we evaluated in vivo effects of salubrinal using the OVX mice and in vitro effects of salubrinal using bone marrowderived cells isolated from the RANKL-injected mice.

In the RANKL administration model, RANKL is subcutaneously injected for as a short period as 3 days [26]. RANKL is a cytokine belonging to the tumor necrosis factor family. In the immune system, it is involved in dendritic cell maturation, while in the skeletal system it is a ligand for osteoprotegerin (OPG) and functions as a key regulator for osteoclast differentiation and activation $[27,28]$. RANKL deletion in mice leads to osteopetrosis and a decrease of osteoclasts, while RANKL overproduction is linked to a variety of degenerative bone diseases including osteoporosis and rheumatoid arthritis $[29,30]$.

Focusing on the development of bone marrow-derived cells in the presence and absence of salubrinal, we addressed a pair of questions: Does administration of salubrinal modulate cellular fates and functions of bone marrowderived cells in favor of prevention of bone loss? If so, are salubrinal's actions more potent to the cells isolated from the osteoporotic RANKL-injected mice than those isolated from the control mice? Because of the anticipated role of salubrinal that is potentially opposite to that of RANKL, we hypothesized that salubrinal is more effective in inhibiting development of osteoclasts and stimulating development of osteoblasts in the cells isolated from the RANKL-injected mice than those from the control mice. To test the hypothesis, we employed assays such as colony-forming unit - granulocyte/macrophages (CFU-GM), colony-forming unit - macrophages (CFU-M), and formation of multi-nucleated osteoclasts in an osteoclast differentiation medium, as well as assays for migration and adhesion of pre-osteoclasts. We also conducted assays for examining colony-forming unit - osteoblasts (CFUOBL) in an osteoblast differentiation medium. To evaluate salubrinal's effects on expression of nuclear factor of activated $\mathrm{T}$ cells $\mathrm{c} 1$ (NFATc1), a master transcription factor for osteoclastogenesis, we conducted real-time PCR and Western blot analysis.

\section{Methods}

\section{Animals and materials preparation}

C57BL/6 female mice (7 weeks of age) were used. Each cage housed four to five mice at the Indiana University Animal Care Facility. They were fed with mouse chow and water ad libitum. Experimental procedures were approved by the Indiana University Animal Care and Use Committee and were in compliance with the Guiding Principles in the Care and Use of Animals endorsed by the American Physiological Society. Cytokines were purchased from PeproTech (Rocky Hills, NC, USA) and other chemicals from Sigma (St. Louis, MO, USA) unless otherwise stated. Salubrinal (R\&D Systems, Minneapolis, $\mathrm{MN}$, USA) was administered at $1 \mathrm{mg} / \mathrm{kg}$ to mice, and at 0.5 to $5 \mu \mathrm{M}$ to cultured cells for the duration of each experiment.

\section{Ovariectomy}

The animal was anesthetized with $1.5 \%$ isoflurane at a flow rate of 0.5 to $1.0 \mathrm{~L} / \mathrm{min}$. After removing the hair, the skin at the operative sites was cleaned using 70\% alcohol and $10 \%$ providoneiodine solution. An incision $(\sim 20 \mathrm{~mm})$ was made at the midline dorsal skin, and the peritoneal cavity was incised to access the ovaries. After removing the ovaries, the wound was closed by suturing. In 4 weeks after surgery, subcutaneous injection of salubrinal was conducted daily at a dose of $1 \mathrm{mg} / \mathrm{kg}$ body weight for 4 weeks. The control OVX mice received an equal volume of vehicle.

\section{RANKL administration for the bone loss model}

Soluble recombinant murine RANKL (sRANKL; PeproTech) was injected subcutaneously using a $1 \mathrm{mg} / \mathrm{kg}$ dosage in $100 \mu \mathrm{l}$ PBS at $24 \mathrm{~h}$ intervals for 3 days [26]. The same 
volume of PBS was injected into vehicle control mice. At $90 \mathrm{~min}$ after the final injection, the mice were euthanized. Iliac bones, femora, and tibiae were harvested, and bone marrow-derived cells were collected.

\section{Determination of bone mineral density (BMD) and bone mineral content (BMC)}

The BMD $\left(\mathrm{g} / \mathrm{cm}^{2}\right)$ and BMC $(\mathrm{g})$ of an entire humerus and ulna were determined using peripheral dual energy X-ray absorptiometry (DXA; PIXImus II, Lunar Corp., Madison, WI, USA) and its software (version 1.47).

\section{Colony-forming unit-granulocyte-macrophages (CFU-GM) assay}

As previously described, a colony-forming unit-granulocyte-macrophage (CFU-GM) assay was conducted [31-33]. Approximately $2.5 \times 10^{4}$ bone marrow-derived cells were prepared from the vehicle control and RANKL-treated mice and seeded onto a 35-mm gridded dish composed of methylcellulose supplemented with $30 \mathrm{ng} / \mathrm{ml}$ murine macrophage-colony stimulating factor (M-CSF), and $20 \mathrm{ng} /$ ml RANKL. Three dosages of salubrinal (1, 2, and $5 \mu \mathrm{M})$ were administered, and cells were cultured at $37^{\circ} \mathrm{C}$ in a $5 \%$ $\mathrm{CO}_{2}$ incubator for 7 days.

\section{Colony-forming unit-macrophage/mononuclear (CFU-M) assay}

Using bone marrow mononuclear cells (BMMNCs), a colony-forming unit-macrophage/mononuclear (CFU-M) assay was conducted, as described previously [34-37]. From the vehicle control and RANKL administration mice, approximately $2.5 \times 10^{4}$ bone marrow-derived cells were prepared. Cells were seeded onto a $35-\mathrm{mm}$ gridded dish, which was composed of methylcellulose supplemented with $30 \mathrm{ng} / \mathrm{ml} \mathrm{M-CSF}$ and $20 \mathrm{ng} / \mathrm{ml}$ RANKL. Three dosages of salubrinal $(1,2$, and $5 \mu \mathrm{M})$ were administered, and cells were cultured at $37^{\circ} \mathrm{C}$ in a $5 \% \mathrm{CO}_{2}$ incubator for 7 days.

\section{Isolation of bone marrow-derived cells for osteoclast development}

Bone marrow-derived cells were collected by flushing the iliac, femur and tibia with Iscove's MEM (Gibco-Invitrogen, Carlsbad, CA, USA) containing $2 \%$ fetal bovine serum using a 23-gauge needle, as described previously [34,38]. Low-density gradient centrifugation was used to separate the cells, which were then cultured in $\alpha$-MEM supplemented with 10\% FBS, $30 \mathrm{ng} / \mathrm{ml} \mathrm{M-CSF}$, and $20 \mathrm{ng} / \mathrm{ml}$ murine receptor activator of nuclear factor kappa-B ligand (RANKL). Culture medium was replaced by $\alpha$-MEM supplemented with $10 \% \mathrm{FBS}, 30 \mathrm{ng} / \mathrm{ml} \mathrm{M-CSF}$, and 60 $\mathrm{ng} / \mathrm{ml}$ RANKL on the third day, and cells were then grown for an additional 3 days.

\section{Osteoclast differentiation assay}

Using bone marrow-derived cells isolated from the vehicle control and RANKL-treated mice with administration of salubrinal $(0,1,2$, and $5 \mu \mathrm{M})$ in 96-well plates, an osteoclast differentiation assay was performed, as described previously $[34,39,40]$. For one experimental condition, salubrinal was applied on day 0 to day 6 (6 days), while in the other experimental condition, it was applied on day 4 to day 6 (3 days). Culture medium was exchanged once on day 4 during the 6-day experiments. A tartrate resistant acid phosphate (TRACP)-staining kit was used according to the manufacturer's instructions to fix and stain adherent cells. TRACP-positive multinuclear cells (> 3 nuclei) were identified as osteoclasts, and their numbers were counted [39]. The osteoclast formation assay was performed at least 3 times using cells isolated independently from different cohorts of mice.

\section{Osteoclast migration assay}

Using a transwell assay, migration of osteoclasts was evaluated as described previously with minor modifications [41]. After isolating them from vehicle control and RANKL-treated mice, bone marrow-derived cells $\left(2 \times 10^{6} / \mathrm{ml}\right)$ were cultured in M-CSF and RANKL in 6-well plates for 4 days, and then trypsinized in Hank's balanced salt solution. With and without salubrinal $(2 \mu \mathrm{M})$, the osteoclast precursor cells $\left(1 \times 10^{5}\right.$ cells/well $)$ were loaded onto the upper chamber of transwells and allowed to migrate to the bottom chamber through an $8-\mu$ m polycarbonate filter coated with vitronectin (Takara Bio Inc., Otsu, Shigma, Japan). $\alpha$-MEM consisting of $1 \%$ bovine serum albumin (BSA) and $30 \mathrm{ng} / \mathrm{ml}$ of M-CSF was in the bottom chamber. After reacting for $6 \mathrm{~h}$, the osteoclast precursor cells in the lower chamber was stained with crystal violet and counted.

\section{Osteoclast adhesion assay}

Ninety-six well plates were coated with $5 \mu \mathrm{g} / \mathrm{ml}$ vitronectin in $\alpha$-MEM supplemented with $30 \mathrm{ng} / \mathrm{ml} \mathrm{M-CSF}$ and were applied with osteoclast precursors $\left(1 \times 10^{5}\right.$ cells/well $)$ in the presence and absence of salubrinal $(2 \mu \mathrm{M})$, as described previously [41]. Cells were incubated for $30 \mathrm{~min}$, then washed with PBS three times and fixed with $4 \%$ paraformaldehyde at room temperature for 10-15 min. After crystal violet staining, the number of cells adherent to $\alpha_{v} \beta_{3}$ integrin was counted.

\section{Osteoblast differentiation assay}

Bone marrow-derived cells were plated at $2 \times 10^{6} / \mathrm{ml}$ in 6-well plates in osteogenic differentiation medium (MesenCult proliferation kit) supplemented with $10 \mathrm{nM}$ dexamethasone, $50 \mu \mathrm{g} / \mathrm{ml}$ ascorbic acid 2-phosphate, and $10 \mathrm{mM} \beta$-glycerophosphate to induce osteogenic differentiation, as described previously $[39,41,42]$. Cells were 
cultured for 2 weeks in the presence and absence of salubrinal $(0.5 \mu \mathrm{M})$, and medium was changed every other day. For alkaline phosphatase (ALP) staining, cells were fixed in citrate-buffered acetone for $30 \mathrm{~s}$, incubated in the alkaline-dye mix for $30 \mathrm{~min}$, and counterstained with Mayer's Hematoxylin for $10 \mathrm{~min}$. Cells were then evaluated microscopically and the intensity of ALP staining was determined.

To evaluate the effects of RANKL administration on multiple developmental stages starting from bone marrowderived cells to mature osteoclasts, the RANKL-driven alterations in CFU-GM, CFU-M, osteoclast formation, migration, and adhesion were determined as fold-changes of the RANKL-injected mice to the vehicle control mice. Furthermore, to quantify efficacy of salubrinal in various developmental stages in osteoclastogenesis, the degree of suppression was measured with reduction ratios between the samples treated with and without $2 \mu \mathrm{M}$ salubrinal.

\section{Expression analysis of NFATc1 in bone marrow-derived cells and RAW264.7 pre-osteoclast cells}

For Western blot analysis, RAW264.7 mouse monocyte/ macrophage cells (ATCC, Manassas, VA, USA) were grown in $\alpha-M E M$ containing $10 \%$ fetal bovine serum and antibiotics (50 units/ml penicillin, and $50 \mu \mathrm{g} / \mathrm{ml}$ streptomycin; Life Technologies, Grand Island, NY, USA). To induce osteoclastogenesis, $20 \mathrm{ng} / \mathrm{ml}$ of RANKL was administered. Bone marrow-derived cells or RAW264.7 cells were lysed in a radioimmunoprecipitation assay (RIPA) lysis buffer, containing protease inhibitors (Santa Cruz Biotechd, Santa Cruz, CA, USA) and phosphatase inhibitos (Calbiochem, Billerica, MA, USA). Isolated proteins were fractionated using 10\% SDS gels and electro-transferred to ImmobilonP membranes (Millipore, Billerica, MA, USA). Antibodies specific to NFATc1 (Santa Cruz), and $\beta$-actin (Sigma) were employed. Protein levels were assayed using a SuperSignal west femto maximum sensitivity substrate (Thermo Scientific). The bands were scanned with Adobe Photoshop CS2 (Adobe Systems, San Jose, CA, USA) and their intensities were quantified using Image J.

In quantitative PCR, total RNA was extracted using an RNeasy Plus mini kit (Qiagen, Germantown, MD, USA) and reverse transcription was conducted with high capacity cDNA reverse transcription kits (Applied Biosystems, Carlsbad, CA, USA). Real-time PCR was performed using Power SYBR green PCR master mix kits (Applied Biosystems). The PCR primers were: NFATc1 (5'-GGT GCT GTC TGG CCA TAA CT-3'; and 5'-GCG GAA AGG TGG TAT CTC AA-3'), tartrate-resistant acid phosphatase (TRACP) (5'- TCC TGG CTC AAA AAG CAG TT -3'; and 5'- ACA TAG CCC ACA CCG TTC TC -3'); and GAPDH (5'-TGC ACC ACC AAC TGC TTA G-3'; and 5'-GGA TGC AGG GAT GAT GTT C-3'), in which $\mathrm{GAPDH}$ was used for internal control. Since
TRACP is highly expressed in osteoclasts, we used its mRNA expression level as a marker for development of osteoclasts. The relative mRNA abundance for the selected genes with respect to the level of GAPDH mRNA was expressed as a ratio of $S_{\text {treated }} / S_{\text {control, }}$ where $S_{\text {treated }}$ is the mRNA level for the cells treated with salubrinal, and $S_{\text {treated }}$ is the mRNA level for control cells.

\section{Statistical analysis}

The data were expressed as mean \pm standard error of mean (SEM). Student's $t$-test was conducted for two-group comparisons. For many-group comparisons, one-way ANOVA was used, followed by a post-hoc test using Fisher's protected least significant difference. All comparisons were two-tailed, and statistical significance was assumed at $p<0.05$. The asterisks $\left(*\right.$, **; and ${ }^{* * * *}$ ) represent $p<0.05, p<0.01$, and $p<0.001$, respectively.

\section{Results}

\section{Evaluation of BMD and BMC of the OVX mice and} RANKL-injected mice

Four-week daily administration of salubrinal at a dose of 1 $\mathrm{mg} / \mathrm{kg}$ to the OVX mice significantly elevated both BMD and BMC of a whole body (Figure 1A-B). Three-day administration of RANKL at a dose of $1 \mathrm{mg} / \mathrm{kg}$, however, significantly decreased BMD and BMC of the humerus and ulna $(\mathrm{N}=6$; both $p<0.05)$ (Figure $1 \mathrm{C}-\mathrm{D})$. Using the RANKL-injected mice, bones from the Iliac, femora, and tibiae were harvested. Bone marrow-derived cells were collected from those bones for examining the effects of salubrinal on developments of osteoclasts and osteoblasts.

\section{Reduction in the number of CFU-GM by salubrinal in a dosage-dependent manner}

To determine the effects of salubrinal on the proliferation of osteoclast progenitors, the CFU-GM assay was conducted using bone marrow-derived cells isolated from the RANKL-injected mice. Salubrinal at 1, 2, and 5 $\mu \mathrm{M}$ reduced the total number of CFU-GM in the femur in a dosage-dependent manner $(p<0.05$ for $1 \mu \mathrm{M}$ salubrinal; $p<0.01$ for $2 \mu \mathrm{M}$; and $p<0.001$ for $2 \& 5$ $\mu \mathrm{M})$ in the RANKL-injected mice (Figure 2A). The CFU-GM numbers were 37,177 $\pm 1,919$ (vehicle control) and 53,213 $\pm 3,545$ (RANKL administration, $p<0.001$ ) (Figure 2B). The CFU-GM numbers were reduced by administration of salubrinal at $2 \mu \mathrm{M}$ for 7 days by $28.5 \%$ $(p<0.001)$ in vehicle control and 30.8\% $(p<0.001)$ in the RANKL-injected mice.

\section{Reduction in the number of CFU-M by salubrinal in a dosage -dependent manner}

To determine the effects of salubrinal on the population of osteoclast progenitors, the CFU-M assay was performed using bone marrow-derived cells isolated from the 

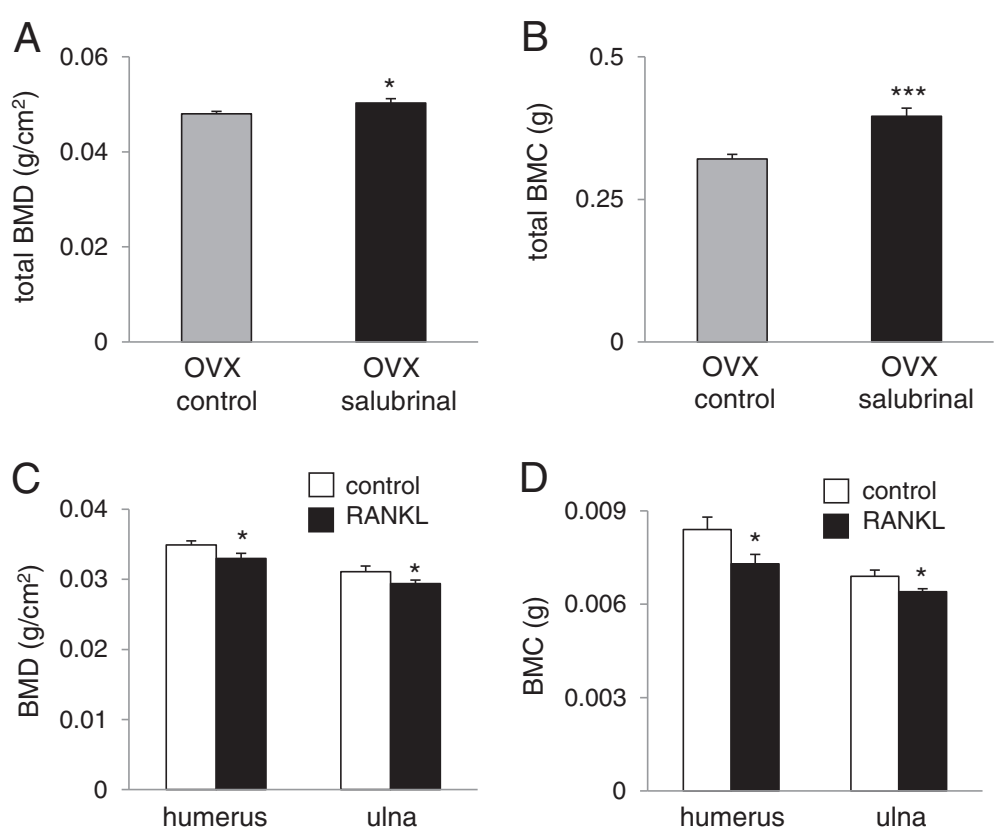

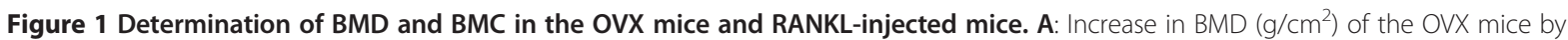
salubrinal ( $(\mathrm{N}=8)$. B: Increase in BMC $(\mathrm{g})$ of the OVX mice by salubrinal $(\mathrm{N}=8)$. $\mathbf{C}$ : Decrease in $\mathrm{BMD}\left(\mathrm{g} / \mathrm{cm}^{2}\right)$ of the humerus and ulna of the RANKL-injected mice $(N=6)$. D: Decrease in BMC $(g)$ of the humerus and ulna $(N=6)$.

RANKL-injected mice. Consistent with the CFU-M numbers, administration of salubrinal at 1,2 , and $5 \mu \mathrm{M}$ reduced the total number of CFU-M in the femur in a dosage-dependent manner (all $p<0.001$ in three dosages) (Figure 3A). The CFU-M numbers were 10,602 \pm 396 (vehicle control) and 18,648 \pm 760 (RANKL administration, $p<0.001$ ) (Figure 3B). Administration of salubrinal at 2 $\mu \mathrm{M}$ for 7 days, for instance, reduced the CFU-M number by $41.2 \%(p<0.001)$ in vehicle control and $43.1 \%(p<0.001)$ in the RANKL-injected mice.

\section{Suppression of osteoclast differentiation by salubrinal in a dosage- and time-dependent manner}

Compared to the bone marrow-derived cells isolated from the vehicle control, the cells from the RANKLinjected mice exhibited an increase in the surface area occupied by multi-nucleated osteoclasts $(24.8 \pm 1.0 \%$ in vehicle control, and $36.5 \pm 1.3 \%$ in RANKL administration) (Figure 4A). A series of images show that the process of osteoclast fusion was accelerated by administration of salubrinal. To evaluate the effects of salubrinal, three dosages of salubrinal $(1,2$, and $5 \mu \mathrm{M})$ were applied. In the cultures salubrinal was applied on day 0 for 6 days, administration of salubrinal resulted in a significant decrease in the surface area covered by multi-nucleated osteoclasts for vehicle control (all $p<0.001$ ) and RANKL administration (all $p<0.001$ ) (Figure 4A). In the cultures salubrinal was applied on day 3 for 4 days, the reduction of the area was also observed (all $p<0.001$ )
(Figure 4B). A series of images indicate that the cellular fusion was reduced by salubrinal administration in a time-and dose-dependent manner.

To further evaluate potential effects of the period of salubrinal administration on osteoclast formation, we compared the results of two sets of experiments in which salubrinal at $2 \mu \mathrm{M}$ was administered from days 0 to 6 , and days 4 to 6 . The result revealed that salubrinal administration at day 0 presented larger reduction in osteoclast formation than that at day 4 in the vehicle control and RANKL-injected groups (both $p<0.001$ ) (Figure 4C).

\section{Suppression of migration and adhesion of pre-osteoclasts} by salubrinal

Pre-osteoclast cells isolated from the RANKL-injected mice were more migratory $(304.1 \pm 12.2$ cells $)$ than those from the vehicle control $(190.4 \pm 5.9$ cells, $p<0.001)$, and the RANKL-driven increase was $37.4 \%$ (Figure $5 \mathrm{~A}$ ). However, salubrinal suppressed the amount of migration by $33.0 \%$ in vehicle control $(p<0.001)$ and by $53.2 \%$ in RANKL administration $(p<0.001)$. In the M-CSF mediated adhesion assay to $\alpha_{\mathrm{V}} \beta_{3}$, the cells isolated from the RANKL-injected mice presented an increase in adhesion by $59.8 \%(142.5 \pm 3.9$ cells $)$ over those from the vehicle control (57.3 \pm 1.8 cells, $p<0.001)$ (Figure 5B). Administration of salubrinal presented significant reduction in cell adhesion by $32.4 \%$ in vehicle control $(p<0.001)$ and by $53.7 \%$ in RANKL administration $(p<0.001)$. 


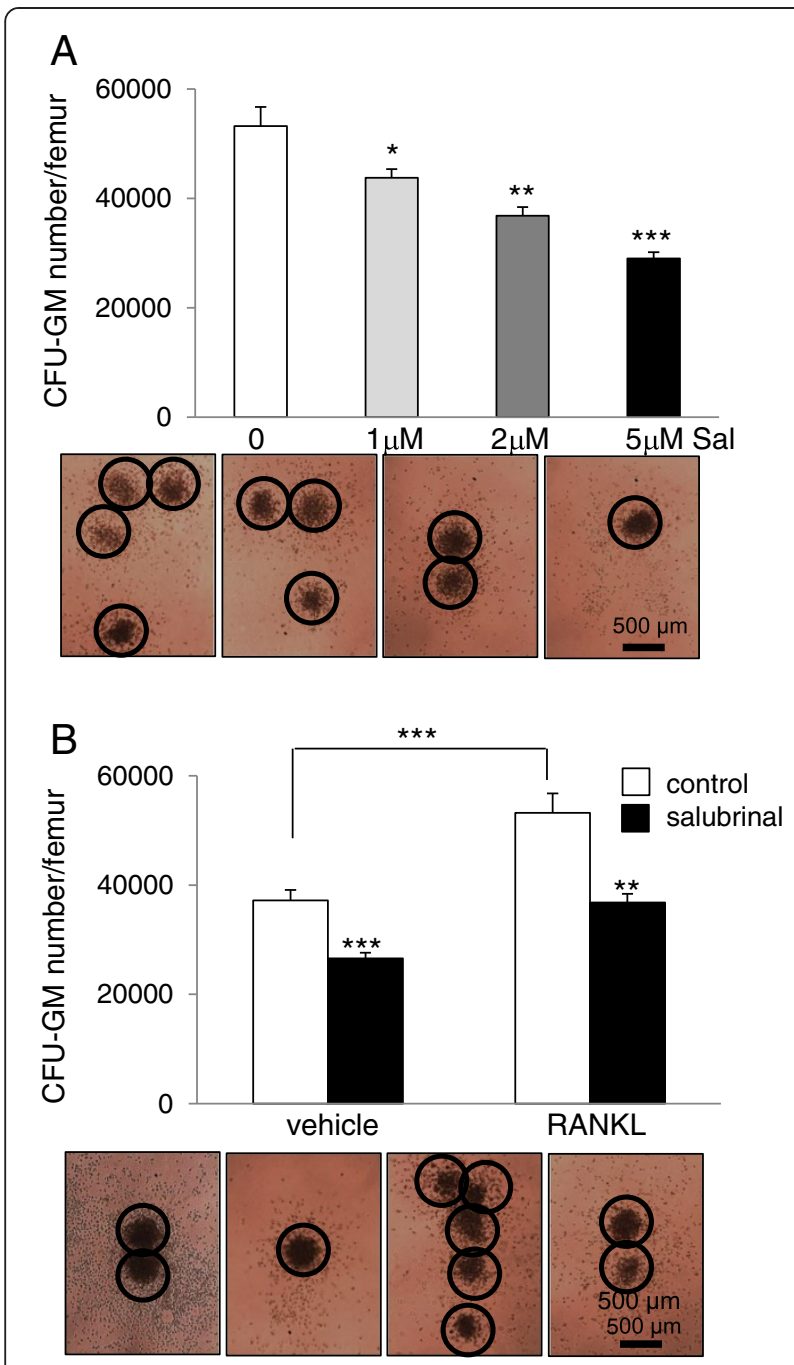

Figure 2 Effects of salubrinal on colony-forming unitgranulocyte-macrophage (CFU-GM). Approximately $2.5 \times 10^{4}$ bone marrow-derived cells were prepared and seeded onto a $35-\mathrm{mm}$ gridded dish supplemented with $30 \mathrm{ng} / \mathrm{ml}$ murine M-CSF and $20 \mathrm{ng} / \mathrm{ml}$ RANKL. Three dosages of salubrinal $(1,2$, and $5 \mu \mathrm{M})$ were administered, and cells were cultured for 7 days. A: Salubrinal-induced reduction in CFU-GM numbers in the RANKL-injected mice using three dosage of salubrinal. The images exhibit the 4 different CFU-GM cultures, in which the circles indicate the colonies. B: Comparison of CFU-GM numbers in the vehicle control and RANKL-injected mice with and without in vitro administration of salubrinal. The representative microphotographs are shown, displaying 4 CFU-GM cultures with colonies in circle. Bar $=500 \mu \mathrm{m}$.

\section{Promotion of osteoblast differentiation by salubrinal}

In the CFU-OBL assay, a significant increase in the number of ALP positive cells was detected by administration of salubrinal. Without salubrinal, the percentage of ALPpositive cells was $18.3 \pm 2.3 \%$ in vehicle control and $20.4 \pm 2.0 \%$ in RANKL administration $(p<0.001)$ (Figure 6 ). Administration of salubrinal at $0.5 \mu \mathrm{M}$ increased the percentage of ALP-positive cells to $23.5 \pm 1.1 \%$ in vehicle
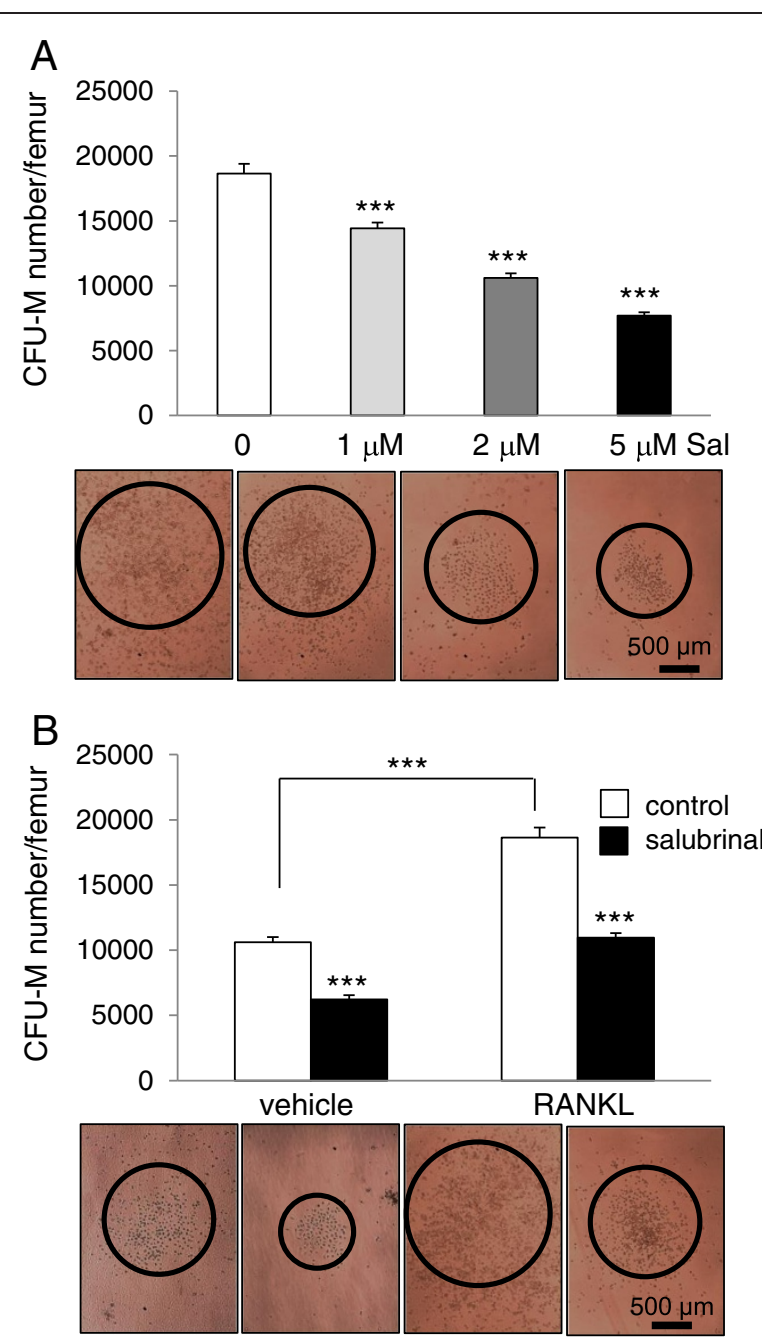

Figure 3 Effects of salubrinal on colony-forming unit-macrophage/ monocyte (CFU-M). Approximately $2.5 \times 10^{4}$ bone marrow mononuclear cells were prepared and seeded onto a $35-\mathrm{mm}$ gridded dish supplemented with $30 \mathrm{ng} / \mathrm{ml}$ M-CSF and $20 \mathrm{ng} / \mathrm{ml}$ RANKL. Three dosages of salubrinal $(1,2$ and $5 \mu \mathrm{M})$ were administered and cells were cultured for 7 days. A: Salubrinal-induced reduction in CFU-M numbers in the RANKL-injected mice using three dosage of salubrinal. The images exhibit the 4 different CFU-M cultures, in which the circles indicate the colonies. B: Comparison of CFU-M numbers in the vehicle control and RANKL-injected mice with and without in vitro administration of salubrinal. The representative microphotographs are shown, displaying 4 CFU-M cultures with colonies in circle. Bar $=500 \mu \mathrm{m}$.

control $(p<0.05)$ and $28.8 \pm 2.3 \%$ in RANKL administration $(p<0.01)$ (Figure 6).

\section{Downregulation of NFATc1 by salubrinal in bone} marrow-derived cells and RAW264.7 pre-osteoclast cells Bone marrow-derived cells were incubated with RANKL in the presence and absence of salubrinal. Incubation with $20 \mathrm{ng} / \mathrm{ml}$ RANKL markedly increased the level of NFATc1, a master transcription factor for development of osteoclasts, and administration of $1 \mu \mathrm{M}$ salubrinal 

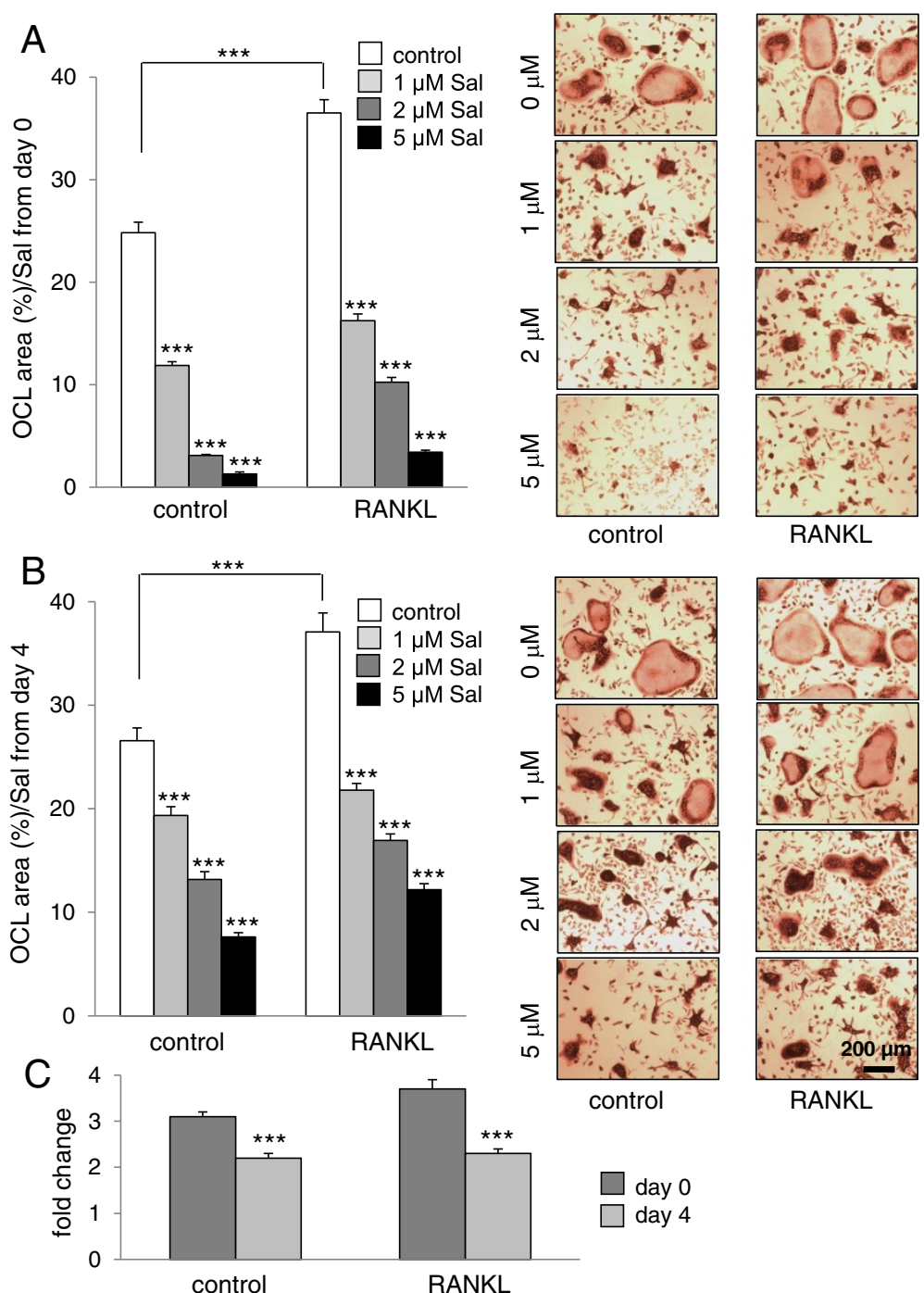

RANKL

Figure 4 Effects of administration of salubrinal on multi-nucleated osteoclast formation. Using bone marrow-derived cells isolated from the vehicle control and RANKL-treated mice, an osteoclast differentiation assay was performed. The culture medium was exchanged once on day 4 during the 6-day experiments. TRACP-positive multinuclear cells (> 3 nuclei) were identified as osteoclasts. The areas covered by multi-nucleated osteoclasts are quantified in response to 3 doses of salubrinal $(1,2$, and $5 \mu \mathrm{M})$. The microphotographs represent the two groups of osteoclast cultures (vehicle control and RANKL administration) with TRACP staining. Bar $=200 \mu \mathrm{m}$. A: Area covered by multi-nucleated osteoclasts in response to in vitro administration of salubrinal from day 0 to day 6 ( 6 days). B: Area covered by multi-nucleated osteoclasts in response to in vitro administration of salubrinal from day 4 to day 6 (3 days). C: Fold change in response to $2 \mu \mathrm{M}$ salubrinal.

reduced the RANKL-driven increase in NFATc1 by $24 \%$ (Figure 7A). To further evaluate the effects of salubrinal, we employed RAW264.7 pre-osteoclast cells. Administration of $20 \mathrm{ng} / \mathrm{ml}$ RANKL elevated the level of NFATc1, and in response to $1-20 \mu \mathrm{M}$ salubrinal the RANKL-induced elevation of NFATc1 was reduced in a dose dependent fashion (Figure 7B). Furthermore, the mRNA levels of NFATc1 and TRACP were increased by RANKL, and their elevation was suppressed by administration of salubrinal (Figure 7C).

\section{Discussion}

The present study presents the beneficial effect of in vivo administration of salubrinal on BMD and BMC of the OVX mice, and in vitro effects on the culture of bone marrow-derived cells isolated from the RANKL-injected and control mice. In the osteoclast assays of CFU-GM, CFU-M, and formation of multi-nucleation, salubrinal significantly reduced the numbers of osteoclastic colonies and cells isolated from both the vehicle control and RANKL-injected mice. In the two sets of maturation 

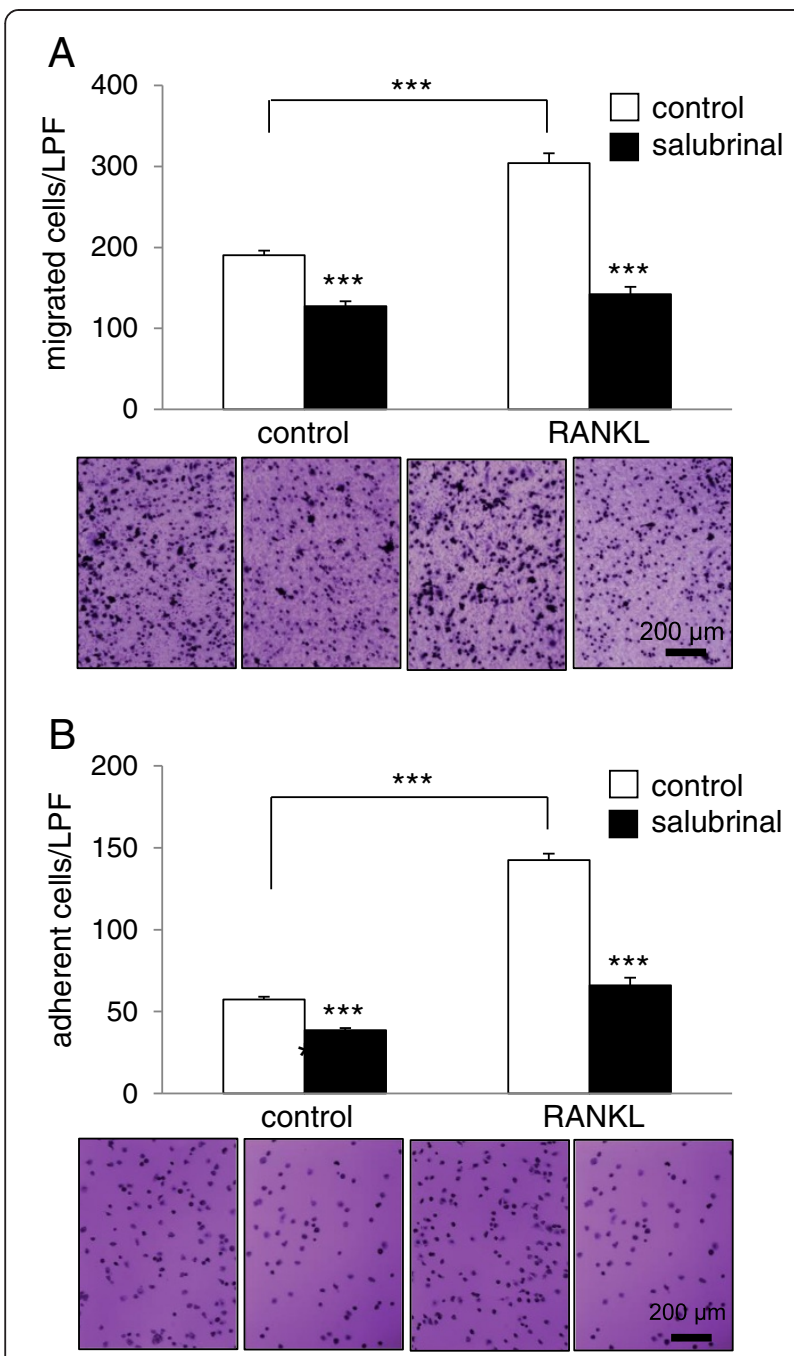

Figure 5 Effects of salubrinal on migration and adhesion of pre-osteoclasts. Bone marrow-derived cells $\left(2 \times 10^{6} / \mathrm{ml}\right)$ were cultured in M-CSF and RANKL in 6-well plates for 4 days to obtain pre-osteoclasts used for the migration and adhesion assays. A: Number of migratory cells. Osteoclast precursor cells $\left(1 \times 10^{5}\right.$ cells/well) were loaded onto the upper chamber of transwells in the presence and absence of $2 \mu \mathrm{M}$ salubrinal. The bottom chamber was filled with a-MEM consisting of $1 \%$ BSA and $30 \mathrm{ng} / \mathrm{ml}$ of M-CSF, and cells were allowed to migrate to the bottom chamber through an $8-\mu \mathrm{m}$ polycarbonate filter coated with vitronectin. After reacting for $6 \mathrm{~h}$, the cells in the lower chamber was stained with crystal violet and counted. The images display 2 pairs of osteoclast cultures. Bar $=200 \mu \mathrm{m}$. B: Number of adherent cells. Ninety-six well plates were coated with 5 $\mu \mathrm{g} / \mathrm{ml}$ vitronectin and filled with a-MEM supplemented with $30 \mathrm{ng} / \mathrm{ml}$ M-CSF. Approximately $1 \times 10^{5}$ osteoclast precursor cells were cultured per well in the presence and absence of $2 \mu \mathrm{M}$ salubrinal for $30 \mathrm{~min}$. Cells were stained with crystal violet and the number of cells adherent to $a_{v} \beta_{3}$ integrin was counted. Bar $=200 \mu \mathrm{m}$.

assays, in which salubrinal was applied from day 0 to 6 and from day 4 to 6 , it suppressed both the early and late stages of osteoclastogenesis. This suppressive effect was larger in the cells isolated from the RANKL-injected mice than the vehicle control mice. In addition to attenuating

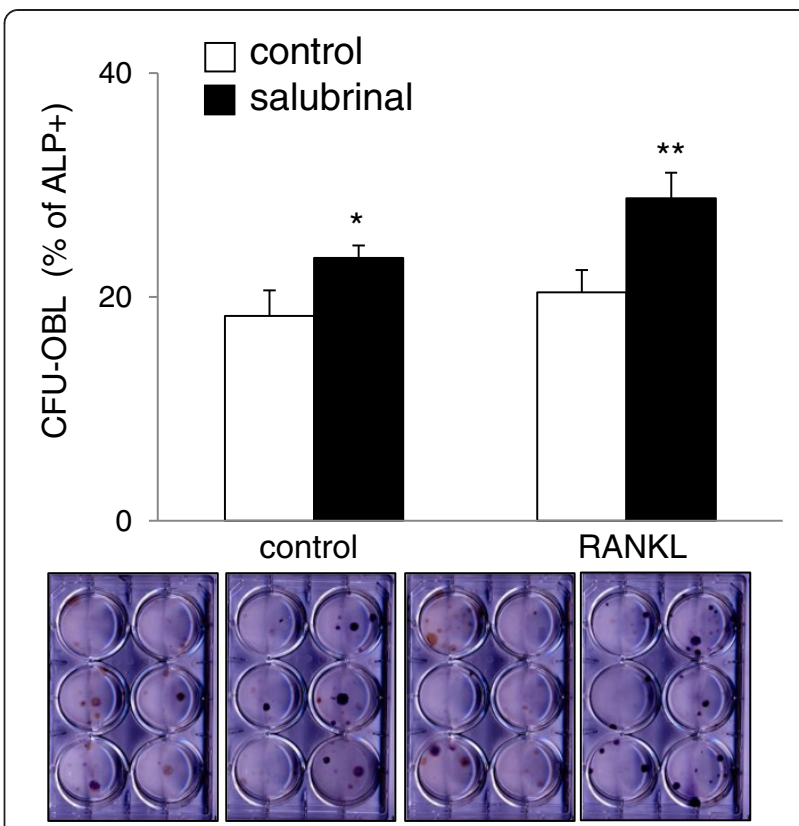

Figure 6 Enhanced osteoblast development by salubrinal in the CFU-OBL assay. Bone marrow-derived cells were plated at $2 \times 10^{6} / \mathrm{ml}$ in 6-well plates in osteogenic differentiation medium supplemented with $10 \mathrm{nM}$ dexamethasone, $50 \mathrm{\mu g} / \mathrm{ml}$ ascorbic acid 2-phosphate, and $10 \mathrm{mM} \beta$-glycerophosphate. Cells were cultured for 2 weeks in the presence and absence of $0.5 \mu \mathrm{M}$ salubrinal, and medium was changed every other day. For alkaline phosphatase (ALP) staining, cells were fixed in citrate-buffered acetone for $30 \mathrm{~s}$, incubated in the alkaline-dye mix for 30 min, and counterstained with Mayer's Hematoxylin for 10 min. Cells were then evaluated microscopically and the intensity of ALP staining was determined. The images display 2 pairs of osteoblast cultures.

osteoclastogenesis, salubrinal was able to reduce adhesion and migration of osteoclasts. Furthermore, it increased the number of CFU-OBL colonies suggesting that it not only inhibits development of osteoclasts but also promotes development of osteoblasts. Quantitative PCR and Western blot analysis revealed that the mRNA and protein levels of NFATc1 were elevated by RANKL, and this elevation was suppressed by administration of salubrinal in a dose dependent fashion.

In evaluating the effects of salubrinal on fates of HSCs and MSCs in bone marrow-derived cells, we employed the recently developed RANKL administration model of osteoporosis. An advantage of this RANKL administration model includes a short period ( 3 days in this study) for induction of osteoclastogenesis, and activation of multiple steps in the development of osteoclasts. In the RANK/ RANKL/OPG signaling pathway, RANKL regulates not only development of osteoclasts but also their activation and survival [43]. RANKL is expressed in bone, bone marrow, and lymphoid tissues including spleen that houses osteoclast precursor cells as macrophages [44]. The RANKL administration model provided a platform to 


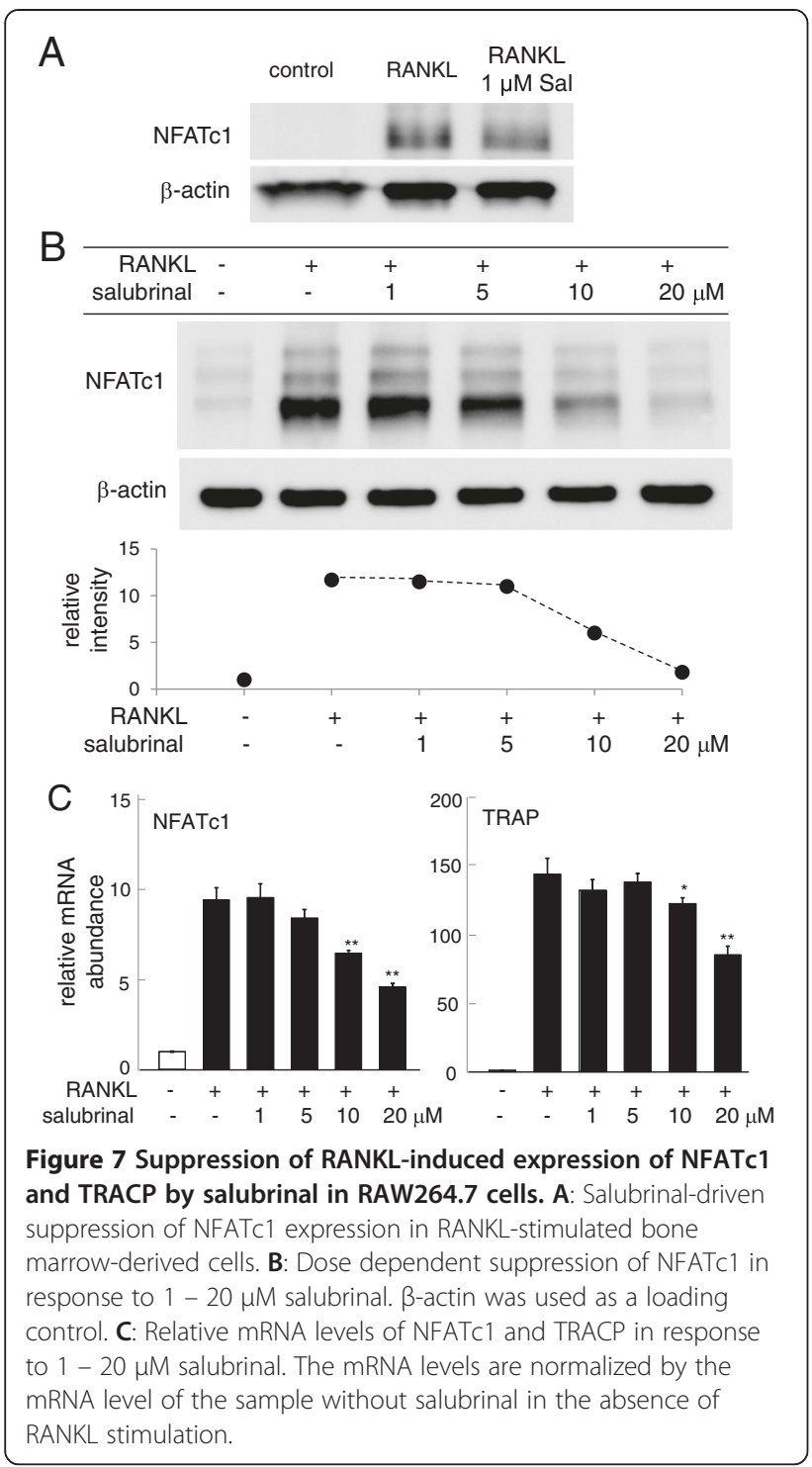

evaluate efficacy of salubrinal as a potential therapeutic agent for preventing osteoclastogenesis and bone resorption. Besides bone resorption, however, RANKL is involved in multiple functions in the immune system such as proliferation of $\mathrm{T}$ cells and inhibition of apoptosis of dendritic cells [45]. It is reported that overproduction of RANKL induces inflammatory bone disorders [46,47]. Thus, the results from any animal model including the RANKL administration model should be confirmed by other animal models and eventually clinical trial.

The regulatory mechanism of salubrinal's action on osteoclastogenesis is not well understood. Salubrinal is known as an inhibitor of serine/threonine-protein phosphatase PP1 and it elevates the phosphorylation level of eIF2 $\alpha($ eIF $2 \alpha-p)$ [48]. The level of eIF2 $\alpha-p$ is upregulated in response to various stresses including viral infection, nutrient deprivation, radiation, and stress to the endoplasmic reticulum [49]. To cope with these cellular insults and reduce apoptosis, the elevated eIF2 $\alpha-p$ in general lowers ribosome's efficiency of protein synthesis except for a group of proteins such as ATF4. Applications of salubrinal have been reported to reduce stress induced apoptosis [50]. We have previously shown that partial silencing of eIF2 $\alpha$ by RNA interference reduces salubrinal-driven downregulation of NFATc1 in RAW264.7 cells [51], and the results in this study indicate that mRNA and protein expression of NFATc1 is downregulated by salubrinal. NFATc1 is a member of the NFAT transcription factor family and a master transcription factor for osteoclast development. It is reported that NFATc1-deficient embryonic stem cells are unable to differentiate into osteoclasts [52]. He et al. has recently shown that NFATc1 expression is regulated at a translational stage in bone marrow macrophage cells, and a phosphorylation mutant plasmid for eIF2 $\alpha$ restored RANKL-induced NFATc1 expression [53]. MafB (V-maf musculoaponeurotic fibrosarcoma oncogene homolog B), IRF8 (interferon regulatory factor 8), and Bcl6 (V cell lymphoma) have been mentioned as inhibitors of NFATc1 [54-56]. Further analysis is necessary for identification of the mechanism of salubrinal's action on NFATc1, which is possibly regulated by eIF $2 \alpha$ alone or any other mediators.

\section{Conclusions}

It is premature to draw any conclusion on development of a potential therapeutic agent for treatment of osteoporosis, but salubrinal possesses several unique features. First, it is a small synthetic chemical agent, which can be taken as an oral pill. Second, it has a dual role of stimulation of bone formation and attenuation of bone resorption. Third, its effects are stronger in the cells isolated from the osteoporotic RANKL-injected mice than those from the control mice. Fourth, it presents dose dependent efficacy in preventing osteoclastogenesis throughout a developmental stage including proliferation, multi-nucleation, and maturation, as well as migration and adhesion. The results herein support the possibility of preventing bone loss through salubrinal-driven regulation of bone marrow-derived cells.

\section{Abbreviations}

OVX: Ovariectomy; BMD: Bone mineral density; BMC: Bone mineral content; elF2a: Eukaryotic translation initiation factor 2 alpha; elF2a-p: Phosphorylated elF2a; NFkB: Nuclear factor kappa B; ATF4: Activating transcription factor 4; NFATC1: Nuclear factor of activated T cells C1; OPG: Osteoprotegerin; RANKL: A Receptor activator of nuclear factor kappa-B ligand; M-CSF: Murine macrophage-colony stimulating factor; BMMNCs: Bone marrow mononuclear cells; MSCs: Mesenchymal stem cells; CFU-M: Colony forming-unit macrophages; CFU-GM: Colony forming-unit granulocyte/macrophages; CFU-OBL: Colony-forming unit - osteoblasts; ALP: Alkaline phosphatase; TRACP: Tartrate resistant acid phosphate; BSA: Bovine serum albumin.

\section{Competing interests}

The authors declare that they have no competing interests. 


\section{Authors' contributions}

$\mathrm{HY}$ participated in experimental designs, and drafted a manuscript. $\mathrm{KH}$ conducted molecular experiments, performed data collection and analysis. AC and TD conducted animal experiments. NT and AA assisted data collection. PZ participated in experimental designs, performed animal and cell experiments, conducted data collection and interpretation, and drafted a manuscript. PZ accepted responsibility for integrity of data analysis. All authors read and approved the final manuscript.

\section{Acknowledgements}

The authors appreciated Enlin Qian for technical support.

\section{Author details}

'Department of Biomedical Engineering, Indiana University-Purdue University Indianapolis, 723 West Michigan Street, SL220, Indianapolis, IN 46202, USA. ${ }^{2}$ Department of Anatomy and Cell Biology, Indiana University School of Medicine, Indianapolis, IN 46202, USA. ${ }^{3}$ School of Basic Medical Sciences, Tianjin Medical University, Tanjin 300070, People's Republic of China.

Received: 26 April 2013 Accepted: 14 June 2013

Published: 1 July 2013

\section{References}

1. van den Bergh JP, van Geel TA, Geusens PP: Osteoporosis, frailty and fracture: implications for case finding and therapy. Nat Rev Rheumatol 2012, 8:163-172.

2. Shiraki M, Kuroda T, Miyakawa N, Fujinawa N, Tanzawa K, Ishizuka A, Tanaka S, Tanaka Y, Hosoi T, Itoi E, Morimoto S, Itabashi A, Sugimoto T, Yamashita T, Gorai I, Mori S, Kishimoto H, Mizunuma H, Endo N, Nishizawa Y, Takaoka K, Ohashi Y, Ohta H, Fukunaga M, Nakamura T, Orimo H: Design of a pragmatic approach to evaluate the effectiveness of concurrent treatment for the prevention of osteoporotic fractures: rationale, aims and organization of a Japanese Osteoporosis Intervention Trial (JOINT) initiated by the Research Group of Adequate Treatment of Osteoporosis (A-TOP). J Bone Miner Metab 2011, 29:37-43.

3. Vercini F, Grimaldi F: PTH 1-84: bone rebuilding as a target for the therapy of severe osteoporosis. Clin Cases Miner Bone Metab 2012, 9:31-36.

4. Dempster DW, Lambing CL, Kostenuik PJ, Grauer A: Role of RANK ligand and denosumab, a targeted RANK ligand inhibitor, in bone health and osteoporosis: a review of preclinical and clinical data. Clin Ther 2012, 34:521-536.

5. Yang $Q$, Jian J, Abramson SB, Huang X: Inhibitory effects of iron on bone morphogenetic protein 2-induced osteoblastogenesis. J Bone Miner Res 2011, 26:1188-1196.

6. Khosla S, Bilezikian JP, Dempster DW, Lewiecki EM, Miler PD, Neer RM Recker RR, Shane E, Shoback D, Potts JT: Benefits and risks of bisphosphonate therapy for osteoporosis. J Clin Endocrinol Metab 2012, 97:2272-2282

7. Riggs BL, Khosla S, Melton LJ III: Sex steroids and the construction and conservation of the adult skeleton. Endocr Rev 2002, 23:279-302

8. Valverde P: Pharmacotherapies to manage bone loss-associated diseases: a quest for the perfect benefit-to-risk ratio. Curr Med Chem 2008, 15:284-304

9. Boras-Granic K, Wysolmerski JJ: PTHrP and breast cancer: more than hypercalcemia and bone metastases. Breast Cancer Res 2012, 14:307.

10. Boyce M, Bryant KF, Jousse C, Long K, Harding HP, Scheuner D, Kaufman RJ, Ma D, Coen DM, Ron D, Yuan J: A selective inhibitor of elF2alpha dephosphorylation protects cells from ER stress. Science 2005, 307:935-939.

11. Huang $X$, Chen $Y$, Zhang $H, M a ~ Q$, Zhang $Y W$, Xu H: Salubrinal attenuates $\beta$-amyloid-induced neuronal death and microglial activation by inhibition of the NF-KB pathway. Neurobiol Aging 2012, 33:1007.e9-1007.e17

12. Saito A, Ochiai K, Kondo S, Tsumagari K, Murakami T, Cavener DR, Imaizum K: Endoplasmic reticulum stress response mediated by the PERK-elF2 (alpha)-ATF4 pathway is involved in osteoblast differentiation induced by BMP2. J Biol Chem 2011, 286:4809-4818.

13. Zhang $P$, Hamamura K, Jiang C, Zhang L, Yokota H: Salubrinal promotes healing of surgical wounds in rat femurs. J Bone Miner Metab 2012, 30:568-579.
14. Li X, Ling W, Khan S, Yaccoby S: Therapeutic effects of intrabone and systemic mesenchymal stem cell cytotherapy on myeloma bone disease and tumor growth. J Bone Miner Res 2012, 27:1635-1648.

15. Sun L, Peng Y, Sharrow AC, labal J, Zhang Z, Papachristou DJ, Zaidi S, Zhu LL, Yaroslavskiy BB, Zhou H, Zallone A, Sairam MR, Kumar TR, Bo W, Braun J, Cardoso-Landa L, Schaffler MB, Moonga BS, Blair HC, Zaidi M: FSH directly regulates bone mass. Cell 2006, 125:247-260.

16. Weitzmann MN, Pacifici R: Estrogen deficiency and bone loss: an inflammatory tale. J Clin Invest 2006, 116:1186-1194.

17. Shahnazari M, Wronski T, Chu V, Williams A, Leeper A, Stolina M, Ke HZ, Halloran B: Early response of bone marrow osteoprogenitors to skeletal unloading and sclerostin antibody. Calcif Tissue Int 2012, 91:50-58.

18. Zhang P, Hammamura K, Yokota H: A brief review of bone adaptation to unloading. Genomics Proteomics Bioinf 2008, 6:4-7.

19. Gaspar AP, Lazaretti-Castro M, Brandão CM: Bone mineral density in spinal cord injury: an evaluation of the distal femur. J Osteoporos 2012, 2012:519754.

20. Jiang SD, Jiang LS, Dai LY: Mechanisms of osteoporosis in spinal cord injury. Clin Endocrinol (Oxf) 2006, 65:555-565.

21. Omi N, Ezawa I: Animal models for bone and joint disease. Low calcium diet-induced rat model of osteoporosis. Clin Calcium 2012, 21:173-180.

22. Chennaiah S, Vijayalakshmi V, Suresh C: Effect of the supplementation of dietary rich phytoestrogens in altering the vitamin D levels in diet induced osteoporotic rat model. J Steroid Biochem Mol Biol 2010, 121:268-272.

23. Lo lacono N, Blair HC, Poliani PL, Marrella V, Ficara F, Cassani B, Facchetti F, Fontana E, Guerrini MM, Traggiai E, Schena F, Paulis M, Mantero S, Inforzato A, Valaperta S, Pangrazio A, Crisafulli L, Maina V, Kostenuik P, Vezzoni P, Villa A, Sobacchi C: Osteopetrosis rescue upon RANKL administration to Rankl (-/-) mice: A new therapy for human RANKL-dependent ARO. J Bone Miner Res 2012, 27:2501-2510.

24. Campbell GM, Ominsky MS, Boyd SK: Bone quality is partially recovered after the discontinuation of RANKL administration in rats by increased bone mass on existing trabeculae: an in vivo micro-CT study. Osteoporosis Int 2011, 22:931-942.

25. Yasuda H: Animal models for bone and joint disease. RANKL-injected bone loss model. Clin Calcium 2011, 21:197-208.

26. Tomimori $Y$, Mori $K$, Koide M, Nakamichi $Y$, Ninomiya T, Udagawa N, Yasuda $\mathrm{H}$ : Evaluation of pharmaceuticals with a novel 50-hour animal model of bone loss. J Bone Miner Res 2009, 24:1194-1205.

27. Wasilewska A, Rybi-Szuminska AA, Zoch-Zwierz W: Serum osteoprotegrin (OPG) and receptor activator of nuclear factor kappaB (RANKL) in healthy children and adolescents. J Pediatr Endocrinol Metab 2009, 22:1099-1104

28. Takayanagi $\mathrm{H}$ : Osteoimmunology and the effects of the immune system on bone. Nat Rev Rheumatol 2009, 5:667-676.

29. Nakamura M, Udagawa N: Osteoporosis and RANKL signal. Clin Calcium 2011, 21:1149-1155.

30. Perlot T, Penninger JM: Development and function of murine B cells lacking RANK. J Immunol 2012, 188:1201-1205.

31. Mun SH, Won HY, Hernandez P, Aguila HL, Lee SK: Deletion of CD74, a putative MIF receptor, in mice enhances osteoclastogenesis and decreases bone mass. J Bone Miner Res 2013, 28:948-959.

32. Droxmeyer HE, Kappes F, Mor-Vaknin N, Legendre M, Kinzforql J, Cooper S, Hangoc G, Markovitz DM: DEK regulates hematopoietic stem engraftment and progenitor cell proliferation. Stem Cells Dev 2012, 21:1449-1454.

33. Kroepfl JM, Pekovits K, Stelzer I, Fuchs R, Zelzer S, Hofmann P, Sedlmayr P, Dohr G, Wallner-Liebmann S, Domej W, Muller W: Exercise increases the frequency of circulating hematopoietic progenitor cells, but reduces hematopoietic colony-forming capacity. Stem Cells Dev 2012, 21:2915-2925.

34. He Y, Rhodes SD, Chen S, Wu X, Yuan J, Yang X, Jiang L, Li X, Takahashi N, Xu M, Mohammad KS, Guise TA, Yang FC: c-Fms Signaling Mediates Neurofibromatosis Type-1 Osteoclast Gain-In-Functions. PLoS One 2012, 7:e46900.

35. Yan D, Gurumurthy A, Wright M, Pfeiler TW, Loboa EG, Everett ET: Genetic background influences fluoride's effects on osteoclastogenesis. Bone 2007, 41:1036-1144.

36. Broxmeyer HE, Mejia JA, Hangoc G, Barese C, Dinauer M, Cooper S: SDF-1/ CXCL12 enhances in vitro replating capacity of murine and human multipotential and macrophage progenitor cells. Stem Cells Dev 2007, 16:589-596. 
37. McHugh KP, Shen Z, Crotti TN, Flannery MR, Fajardo R, Bierbaum BE, Goldring SR: Role of cell-matrix interactions in osteoclast differentiation. Adv Exp Med Biol 2007, 602:107-111.

38. Wu X, Chen S, Orlando SA, Yuan J, Kim ET, Munugalavadla V, Mali RS, Kapur $\mathrm{R}$, Yang FC: p85a regulates osteoblast differentiation by cross-talking with the MAPK pathway. J Biol Chem 2011, 286:13512-13521.

39. Abdallah BM, Ditzel N, Mahmood A, Isa A, Traustadottir GA, Schilling AF, Ruiz-Hidalgo MJ, Laborda J, Amling M, Kassem M: DLK1 is a novel regulator of bone mass that mediates estrogen deficiency-induced bone loss in mice. J Bone Miner Res 2011, 26:1457-1471.

40. Jansen ID, Vermeer JA, Bloemen V, Stap J, Everts V: Osteoclast fusion and fission. Calcif Tissue Int 2012, 90:515-522.

41. Xiao G, Cheng H, Cao H, Chen K, Tu Y, Yu S, Jiao H, Yang S, Im HJ, Chen D, Chen J, Wu C: Critical role of filamin-binding LIM protein 1 (FBLP-1)/ migfilin in regulation of bone remodeling. J Biol Chem 2012, 287:21450-21460.

42. Nabavi N, Khandani A, Camirand A, Harrison RE: Effects of microgravity on osteoclast bone resorption and osteoblast cytoskeletal organization and adhesion. Bone 2011, 49:965-974.

43. Boyce BF, Xing L: The RANKL/RANK/OPG pathway. Curr Osteoporos Rep 2007, 5:98-104.

44. Graham LS, Tintut Y, Parhami F, Kitchen CM, Ivanov Y, Tetradis S, Effros RB: Bone density and hyperlipidemia: the T-lymphocyte connection. J Bone Miner Res 2010, 25:2460-2469.

45. Akiyama T, Shinzawa M, Akiyama N: RANKL-RANK interaction in immune regulatory systems. World J Orthop 2012, 3:142-150.

46. Chang SK, Noss EH, Chen M, Gu Z, Townsend K, Grenha R, Leon L, Lee SY, Lee DM, Brenner MB: Cadherin-11 regulates fibroblast inflammation. Proc Natl Acad Sci U S A 2011, 108:8402-8407.

47. Belibasakis GN, Reddi D, Bostanci N: Porphyromonas gingivalis induces RANKL in T-cells. Inflammation 2011, 34:133-138.

48. Vander Mierde D, Scheuner D, Quintens R, Patel R, Song B, Tsukamoto K Beullens M, Kaufman RJ, Bollen M, Schuit FC: Glucose activates a protein phosphatase-1-mediated signaling pathway to enhance overall translation in pancreatic beta-cells. Endocrinology 2007, 148:609-617.

49. Dey S, Baird TD, Zhou D, Palam LR, Spandau DF, Wek RC: Both transcriptional regulation and translational control of ATF4 are central to the integrated stress response. J Biol Chem 2010, 285:33165-33174.

50. Dou G, Sreekumar PG, Spee C, He S, Ryan SJ, Kannan R, Hinton DR: Deficiency of aB crystallin augments ER stress-induced apoptosis by enhancing mitochondrial dysfunction. Free Radic Biol Med 2012, 53:1111-1122

51. Hamamura K, Tanjung N, Yokota H: Suppression of osteoclastogenesis through phosphorylation of eukaryotic translation initiation factor 2 alpha. J Bone Miner Metab 2013: in press.

52. Takayanagi H: The role of NFAT in osteoclast formation. Ann NY Acad SC 2007, 1116:227-237.

53. He L, Lee J, Jang JH, Sakchaisri K, Hwang J, Cha-Molstad HJ, Kim KA, Ryoo IJ, Lee HG, Kim SO, Soung NK, Lee KS, Kwon YT, Erikson RL, Ahn JS, Kim BY: Osteoporosis regulation by salubrinal through elF2a mediated differentiation of osteoclast and osteoblast. Cell Signal 2013, 25:552-560

54. Kim K, Kim JH, Lee J, Jin HM, Kook H, Kim KK, Lee SY, Kim N: MafB negatively regulates RANKL-mediated osteoclast differentiation. Blood 2007, 109:3253-3259

55. Zhao B, Takami M, Yamada A, Wang X, Koga T, Hu X, Tamura T, Ozato K, Choi $Y$, Ivashkiv $L B$, Takayanagi $H$, Kamijo R: Interferon regulatory factor-8 regulates bone metabolism by suppressing osteoclastogenesis. Nat Med 2009, 15:1066-1071.

56. Miyauchi Y, Ninomiya K, Miyamoto H, Sakamoto A, Iwasaki R, Hoshi H, Miyamoto K, Hao W, Yoshida S, Morioka H, Chiba K, Kato S, Tokuhisa T, Saitou M, Toyama Y, Suda T, Miyamoto T: The Blimp1-Bcl6 axis is critical to regulate osteoclast differentiation and bone homeostasis. J Exp Med 2010, 207:751-762.

doi:10.1186/1471-2474-14-197

Cite this article as: Yokota et al.: Effects of salubrinal on development of osteoclasts and osteoblasts from bone marrow-derived cells. BMC Musculoskeletal Disorders 2013 14:197.

\section{Submit your next manuscript to BioMed Central and take full advantage of:}

- Convenient online submission

- Thorough peer review

- No space constraints or color figure charges

- Immediate publication on acceptance

- Inclusion in PubMed, CAS, Scopus and Google Scholar

- Research which is freely available for redistribution 